\title{
PRELIMINARY INVESTIGATION INTO THE ACUTE ORAL TOXICITY OF Tephrosia vogelii LEAVES IN MICE
}

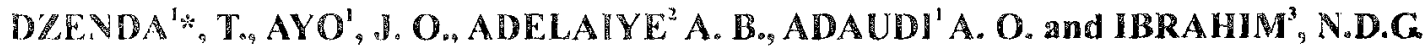 \\ 'Department of Veterinary Physiology and Phamacology, Department of Human Physiology, \\ 'Department of Veterinary Pahology and Microbiology, Ahmadu Bello University, Zaria, Nigeria.
}

* Correspondence: E-mail: drdzenda(Wyahoo.com Tel: +234805 4433410

\begin{abstract}
SUMMARY
An investigation was carried out on the acute toxicity of the crude methanolic leaf extract of Tephrosia vogelii Hook. $f$. (Fabaceae) in mice following oral administration of the extract at doses ranging from 10 to $10,000 \mathrm{mg}$ per $\mathrm{kg}$ body weight. Propylene glycol was used as vehicle of adminisiration. Clinical signs observed included initial excitation, restlessness, dyspnoea, foaming from the mouth, incoordination of gait and clonic convulsions. Gross post-mortem findings in the mice were enteritis, congestion of the lungs, liver, kidneys and spleen. Histopathologic findings included congestion, foeal areas of necrosis and fatty degeneration in the liver; necrosis and oedema at the proximal and distal convoluted and collecting tubules of the kidneys; focal areas of necrosis in the epicardium and myocardium with mononuclear cellular infiltration. The median lethal dose $\left(L D_{50}\right)$ of the extract leaves was $134.16 \mathrm{mg} / \mathrm{kg}$. The clinical signs observed in mice were similar to those reported for rotenone poisoning in mammals. It is concluded that the extract exerted toxic effects, which predominantly involved neurological disorders, hepatic, renal and cardiac necrotic changes in the mice.
\end{abstract}

KFVWORDS: Tephrosia vogeli; Acute toxicity; $\mathrm{LD}_{\mathrm{sp}}$; Mice; Propylene glycol.

\section{RNTRODUCTION}

Tephrosia vogelii Hook. f. (Fabaceae) is a leguminous plant that is widely grown in the tropics, especially in Tropical Africa and India (Lambert et al., 1993), for use mainly as piscicide (Bossard, 1993 and Ibrahim et al., 2000) and insecticide (Chiu, 1989; Kaposhi, 1992 and Ogendo ef al., 2004), but is also used intemally for numerous other ethnomedical purposes, including its use as abortifacient, purgative and emetic (Burkill, 1995). Although the plant's extract is believed to be selectively toxic to fishes and insects (O'Brien and Yamamoto, 1970 and Matsumura, 1975), there are serious concerns about its safety in mammals, especially where it is used internally (Gaisson and Lec, 2000).

The aim of the present study was to investigate the acute toxicity effects of $T$. vogelii leaf extract in mice.

\section{MATERIALSANDMETHODS}

Plant Collection, Extraction and Preparation of extract

Fresh leaves of Tephrosia vogelii were collected in October, 2000 at Bafai-Gora village, $12 \mathrm{~km}$ north of Zonkwa $\left(9^{\circ} 47^{\prime} \mathrm{N}, 8^{\circ} 18^{\prime} \mathrm{E}\right)$ in Kaduna State, Nigeria. The plant was identified and authenticated by an expert in the Savannah Herbarium, National Animal Production Research Institute, Shika-Zaria, Nigeria. The leaves were air-dried, and ground into powder using a grinding machine ("CHRISTY" Chelmsford England, Machine type 8 lab. mill) with sieve diameter of $0.5 \mathrm{~mm}^{2}$ at $8,000 \mathrm{rpm}$. Crude methanolic (methanol, Analar", BDH, England) extraction of the dried ground leaves was carricd out using a Soxhlet extractor. The extract was evaporated to dryness under pressure using a rotary evaporator. Assay extract was 
prepared by dissolving the extract in de-ionized water and filtering with medical cotton wool.

\section{Experimental Animals}

Albino mice (Mus musculus) were purchased from the Department of Veterinary Surgery and Medicine, Ahmadu Bello University (ABU), Zaria. They were kept in mice cages in the Small Animal Room of the Department of Veterinary Physiology and Pharmacology, ABU, Zaria until use. The mice were fed with pellet feed formulated from a combination of chicken grower's mash (Pfizer, Kaduna, Nigeria) and groundnut cake powder mixed at a ratio of $3: 1$. Tap water was given ad libitum.

\section{Acute Oral Toxicity Studies}

Acute oral toxicity studies of the methanolic leaf extract of Tephrosia vogelii in albino mice (Mus musculus) was carried out using modified Lorke's method (1983). A suitable solvent for the extract used in the oral toxicity studies was determined by attempting to dissolve it using four different solvents, which included distilled water, groundnut oil, Tween-20 and propylene glycol.

The Maximum Convenient Concentration (MCC), which was the maximum amount of extract dissolved in $1.0 \mathrm{ml}$ of propylcne glycol such that the solution was delivered through an 18 $G$ needle at room temperature, was determined by measuring $1.0 \mathrm{~g}$ of the extract and adding $0.05 \mathrm{ml}$ of propylene glycol at a time, until the solution was easily dclivered through the needle. From the volume of solvent used, the MCC of the extract in $\mathrm{g} / \mathrm{ml}$ was determined and a stock solution was made and refrigerated until required. The Maximum Convenient Volume (MCV) that can be administered to mice by the oral route is $5 \mathrm{ml} / \mathrm{kg}$ (Loomis, 1978). Therefore, the Maximum Tolerated Dose (MTD, $\mathrm{g} / \mathrm{kg}$ ) of the extract used in this experiment was calculated by multiplying the $\mathrm{MCC}(\mathrm{g} / \mathrm{ml})$ by the $\mathrm{MCV}(\mathrm{ml} / \mathrm{kg})$ as described by Ibrahim (1984).

In the toxicity studies, the mice were fasted for 24 hours and deprived of water for 12 hours before the administration of the extract. An insulin syringe fitted to a curved 18-guage needle with blunt end was used to administer the extract orally. All the mice were weighed and identified with marks using marker pen. Clinical signs of the extract in mice were observed and recorded.

The studies were conducted in two stages. The first stage was the pilot acute toxicity studies and the second stage was that of L.D determination.

In the pilot acute toxicity studies, fifteen mice (19-29.2 g) of both sexes, arranged in five groups of three mice each randomly, were used to determine the amount of extract that was capable of bringing about $0-100 \%$ death when given orally to mice.

Group 1 received $10,000 \mathrm{mg}$ of the extract per kg body weight.

Group 2 received $1_{9}, 000 \mathrm{mg}$ of the extract per $\mathrm{kg}$ body weight.

Group 3 received $100 \mathrm{mg}$ of the extract per $\mathrm{kg}$ body weight.

Group 4 received $10 \mathrm{mg}$ of the extract per $\mathrm{kg}$ body weight.

Group 5 served as control and was given only the vehicle, propylene glycol at $5 \mathrm{ml} / \mathrm{kg}$.

From the pilot studies, the range of doses for $\mathrm{LD}_{50}$ was selected to be between $100 \mathrm{mg}$ and $1000 \mathrm{mg}$ per $\mathrm{kg}$ body weight of mice. Therefore, nine mice were arranged in 3 groups of 3 mice each as follows:

Group 1 received $800 \mathrm{mg}$ of the extract per $\mathrm{kg}$ body weight of mice.

Group 2 received $400 \mathrm{mg}$ of the extract per $\mathrm{kg}$ body weight of mice.

Group 3 received $200 \mathrm{mg}$ of the extract per $\mathrm{kg}$ body weight of mice.

Nine mice were further treated in three groups of three mice each.

Group 1 received $180 \mathrm{mg}$ of the extract per $\mathrm{kg}$ body weight.

Group 2 received $150 \mathrm{mg}$ of the extract per $\mathrm{kg}$ body weight.

Group 3 received $120 \mathrm{mg}$ of the extract per $\mathrm{kg}$ body weight.

From the data obtained in the above studies, the median lethal dose $\left(\mathrm{LD}_{50}\right)$ of the extract in mice was calculated by taking the geometrical mean between the lowest lethal dose that produced $100 \%$ death and the highest non-lethal dose.

Gross post-mortem examination was performed on all the mice in the Necropsy 
Room, Department of Veterinary Pathology and Microbiology, ABL, Zaria. Organs examined included the lungs, liver, heart, spleen, kidneys and intestine. Samples of these organs were taken for histopathologic examinations. They were preserved in universal bottles containing $10 \%$ formalin solution.

Slides for histopathologic examination were prepared and stained with $\mathrm{H} \& \mathrm{E}$ stain (Luna, 1968) in the Histotechniques Laboratory, Depariment of Veterinary Anatomy, Ahmadu Bello University (ABU), Zaria, Nigeria. The slides were observed and photomicrographed at $\times 400$ using a microscope (DIALUX 20, Leitz, Wetzlar) in the Department of Veterinary Pathology and Microbiology, ABU, Zaria, Nigeria.

\section{RESULTS}

The extract was only partially soluble in water. Only about $42.84 \%$ of the extract dissolved in water. It dissolved in groundnut oil and Tween-20 with suspension of particles. It was completely soluble in propylene glycol, after rigorous stirring with a glass rod, and so propylene glycol was used as solvent for the acute toxicity studies.

The results of the pilot test were summarized in Table I. $10,000 \mathrm{mg} / \mathrm{kg}$ and $1,000 \mathrm{mg} / \mathrm{kg}$ caused $100 \%$ mortality $(3 / 3)$, while 100 and $10 \mathrm{mg} / \mathrm{kg}$ caused $0 \%$ mortality $(\%)$. Results obtained from further tests showed that concentrations of 800 , $400,200,180$, and $150 \mathrm{mg} / \mathrm{kg}$ all caused $100 \%$ mortality $\left({ }^{3} / 3\right)$, whereas $120 \mathrm{mg} / \mathrm{kg}$ caused $0 \%$ mortality $\left(\frac{0}{3}\right)$ (Table II).

TABLE I:Resnlts of the pilot test for $L D_{\mathrm{s}}$ of the methanolic leaf extract of Tephrosia vogelii in mice

\begin{tabular}{llll}
\hline Group & $\begin{array}{l}\text { Dose } \\
(\mathrm{mg} / \mathrm{kg})\end{array}$ & $\begin{array}{l}\text { No Dead/ No } \\
\text { Alive }\end{array}$ & \multicolumn{1}{c}{ Clinical Signs } \\
\hline 1 & 10,000 & $3 / 3$ & $\begin{array}{l}\text { Excitation, restlessness, incoordination of gait, clonic } \\
\text { convulsions, burrowing, recumbency, gasping, } \\
\text { depression, stupor, coma and death }\end{array}$ \\
2 & 1,000 & $3 / 3$ & \\
3 & 100 & $0 / 3$ & All of the above, except coma and death \\
4 & 10 & $0 / 3$ & None \\
5 & Control & $0 / 3$ & None \\
\hline
\end{tabular}

TABLE IT:Results of the test for $\mathrm{LD}_{\mathrm{si}}$ of methanolic leaf extract of Tephrosia vogelii

\begin{tabular}{llll}
\hline Group & $\begin{array}{l}\text { Dose } \\
(\mathrm{mg} / \mathrm{kg})\end{array}$ & $\begin{array}{l}\text { No Dead/ No } \\
\text { Alive }\end{array}$ & \multicolumn{1}{c}{ Clinical Signs } \\
\hline 1 & 800 & $3 / 3$ & $\begin{array}{l}\text { Excitation, restlessness, incoordination of gait, clonic } \\
\text { convulsions, gasping, burrowing, depression, } \\
\text { recumbency, stupor, coma and death }\end{array}$ \\
2 & 400 & $3 / 3$ & \\
3 & 200 & $3 / 3$ & \\
4 & 180 & $3 / 3$ & \\
6 & 150 & $3 / 3$ & All of the above, except coma and death \\
\hline
\end{tabular}

Clinical signs included initial excitation, restlessness, dyspnoea (gasping), foaming in the mouth, incoordination of gait, clonic convulsions and burrowing into the litter, followed by recumbency, depression and stupor or coma. The signs appeared within 10-20 seconds of extract administration. Within 10-20 minutes post-administration, most of the mice treated with $150-10,000 \mathrm{mg} / \mathrm{kg}$ of the extract were in coma. Death occurred within 30 minutes to 24 hours. Al] the mice that received 120 and $100 \mathrm{mg} / \mathrm{kg}$ of the extract showed the above clinical signs without going into coma. Clinical signs in the mice that received $10 \mathrm{mg} / \mathrm{kg}$ were mild. The mice that received only the vehicle (propylene glycol) showed no clinical signs. 
DZENDA et al: Acute toxicity of Tephrosia Vogelii leaves in mice

Taking the geometrical mean from the sum of the least lethal dose $(150 \mathrm{mg} / \mathrm{kg}$ ) and the nearest (nonlethal) dose to it $(120 \mathrm{mg} / \mathrm{kg})$, the $L_{s_{0}}$ was calculated to be $134.16 \mathrm{mg} / \mathrm{kg}$.

Gross post-mortem examination of the mice that died as a result of the extract showed enteritis, congestion of the lungs, liver, kidneys and spleen. The liver was also fatty and haemorrhagic in some cases. No gross lesions were observed in control animals and those that survived lower doses.

Histopathologic findings in the mice, which died following administration of the extract, showed necrosis of the intestinal glands and villi with mononuclear cellular infiltration and catarthal enteritis, and mucous secretion by goblet cells (Plate 1). Their livers had congested blood vessels, focal areas of necrosis and fatty degeneration (Plate 2). There was lymphocyte proliferation in the spleen, Payer's patches and lymph nodes (Plate 3 ). The kidneys had areas of necrosis at the proximal and distal convoluted and collecting tubules. There was oedema fluid in some renal tubules. The heart had focal areas of necrosis in the epicardium and myocardium with mononuclear cellular infiltration (Plate 4).

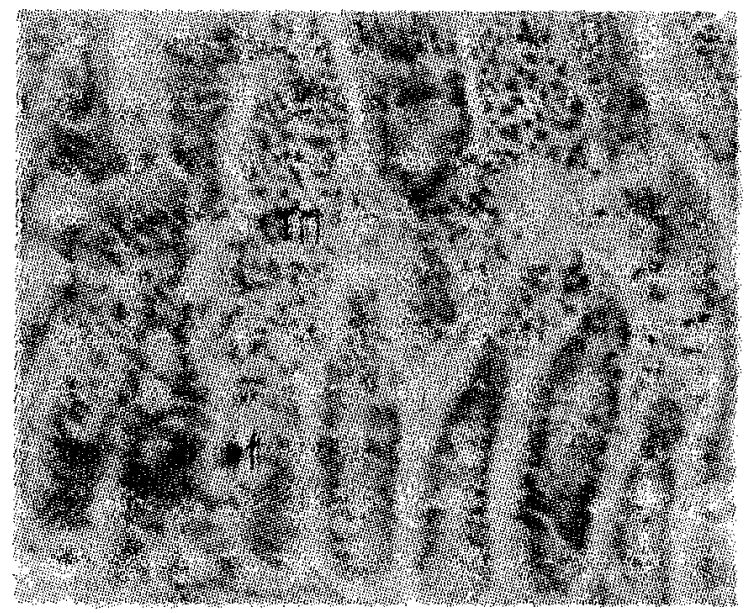

PLATE 1:Section of an intestive from mise treated with Tephrosia vogelii leaf extract $(200 \mathrm{mg} / \mathrm{kg})$. Note focal areas of necrosis (f) and mononirelear cellular infiltration $(m)$ of intestinal glands and villi. $H \& E$ stain (X 400)

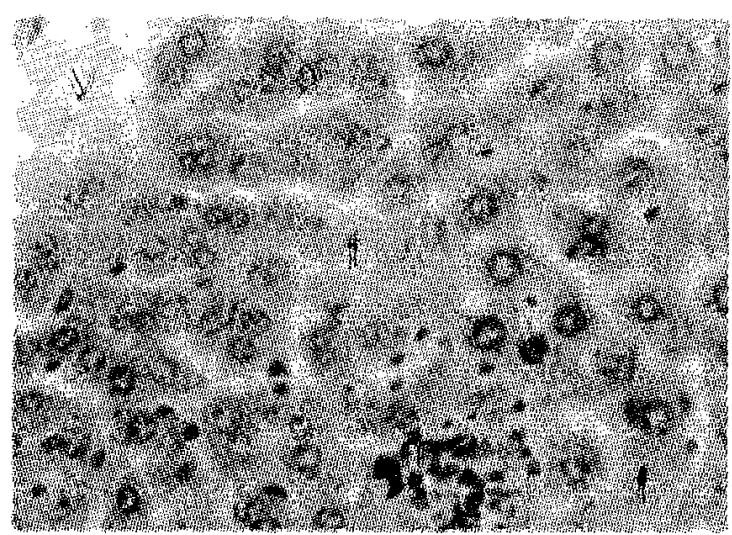

PLATE 2: Section of a liver from mice treated with Tephrosia vogelii leaf extrace $(200 \mathrm{mg} / \mathrm{kg})$. Note the central vein $(V)$, focol areas of necrosis (i) and monon uclear cellelar infiltration $(m)$ of hepatocytes. $H \&$ E stain (X 400)

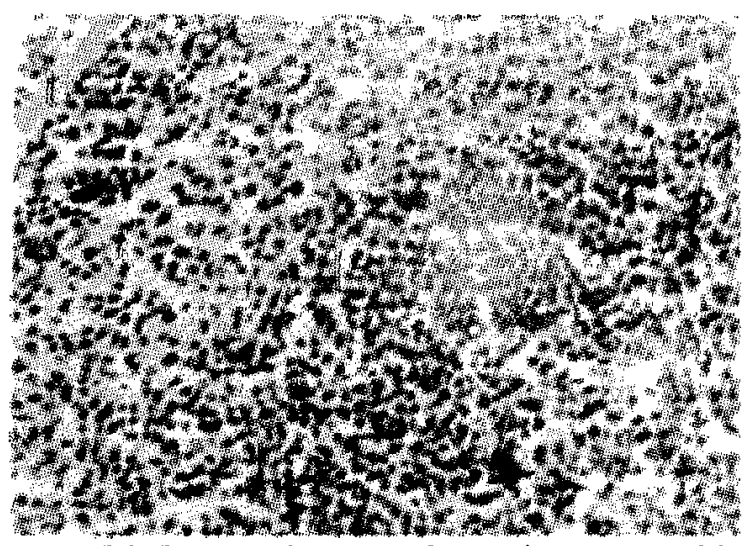

PLATE 3: Section of a spleen from mice treated with Tephrosia vogelii leaf extract $(200 \mathrm{mg} / \mathrm{kg})$. Note the splenic trabeculae $(t)$ and massive probiferation of lymphocytes (L). $H$ \& $E$ stain (X 400)

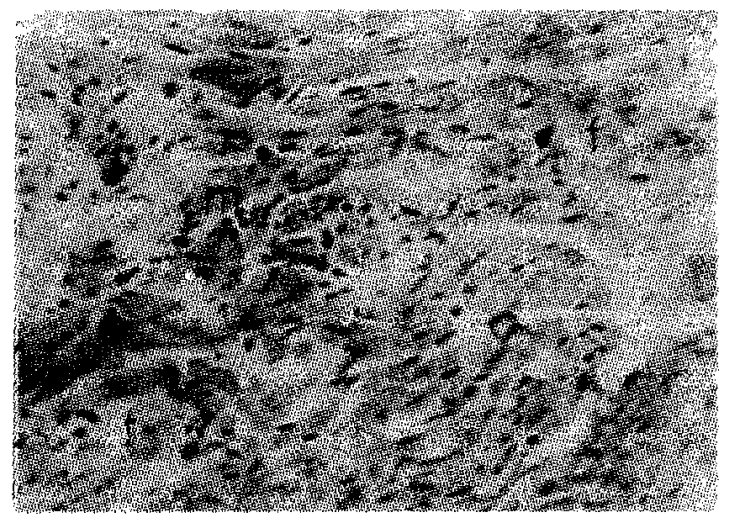

PLATE 4: Section of a heart from mice treated with Tephrosia vogelii leaf extract (200 $\mathrm{mg} / \mathrm{kg})$. Note focal areas of necrosis (f) and mononuclear cellular infiltration $(m)$ of the myocardium. H \& E stain (X 400) 


\section{DISCUSSION}

Clinical signs of restlessness, incoordination (staggering), clonic convulsions (jerking), dyspnoea (gasping), and stupor (near unconsciousness), seen in the mice treated with the extract of Tephrosia vogelii leaves were indicative of respiratory and neural impairments. Poisoning with rotenone, the main toxic ingredient in the plant extract, is known to cause the above clinical signs in mammals as a result of respiratory impairment (stimulation followed by depression) and nerve poisoning (DeWilde, 1986 and Marking, 1988). Thus death occurred from respiratory paralysis; that is, inhibition of respiratory metabolism at the cellular or molecular level (DeWilde, 1986). The oral lethal dose, $L D_{s 0}$, of $134.2 \mathrm{mg} / \mathrm{kg}$ obtained in the present study showed that the extract was moderately toxic to mice, using the oral route and propylene glycol as the vehicle (WHO, 2001). The plant powders have been reported to be more toxic than would be accounted for by the rotenone content, indicating the presence of other extractives which may affect the toxicity (Matsumura, 1975 and Gosselin et al., 1984).

The congestion of visceral organs and fatty or haemorrhagic hepatic degeneration observed in the present study were consistent with the findings of Matsumura (1975). Many organs were affected by the administration of the extract orally to mice. The generalized focal areas of necrosis with lymphocytes and/or mononuclear cellular infiltration observed in all the organs were indicative of cellular death as a result of failure of oxidative phosphorylation to occur, and the body's attempt to get rid of the necrotic debris at these points. Focal areas of necrosis and mild kidney damage have been reported in animals repeatedly fed derris powder (a botanical source containing 9.6 per cent rotenone) at levels from 312 to $5000 \mathrm{ppm}$ (Negherbon, 1957). The results of the present study support the findings that rotenone poisoning causes brain damage in rats, similar to brain damage caused by Parkinson's disease in humans. Consequently, the use of rotenone as insecticide has been temporally suspended in the United Kingdom, pending further research to prove its safety in humans (Gaisson and Lee,
2000).

\section{CONCLUSION}

In conclusion, the crude extract of Tephrosia vogelii leaves was shown to be moderately toxic to mice. Oral administration of the extract to mice at doses $=150 \mathrm{mg} / \mathrm{kg}$ caused clinical and histopathological lesions, which eventually resulted to death. Therefore, prolonged use of the plant extract for ethno-medical and veterinary purposes should be handled with caution.

It is recommended that the effect of $T$. vogelii leaf extract on the brain be investigated in order to ascertain whether it causes brain damage similar to that caused by pure rotenone poisoning.

\section{REFERENCES}

BOSSARD, E. (1993): Angolan Medicinal Plants Used also as Piscicides and/or Soaps. J. Ethnopharmacol., 40:1-19.

BURKILL, H.M. (1995): The Useful Plants of West Tropical Africa. $2^{\text {nt }}$ Edn. Vol. 3. Royal Botanical Gardens, Kew; 857.

CHIU, S.F. (1989): Studies on Plants as a Source of Insect Growth Regulators for Crop Protection. J. Appl. Entomol., 107:185192.

DEWILDE, A.R. (1986): A Case of Fatal Rotenone Poisoning in a Child. $J$. Forens. Sci., 31:1492-1498.

GAISSON, B. and LEE, V. (2000): A New Link between Pesticides and Parkinson's Disease. Nat. Neurosci, 3:1227-1228.

GOSSELIN, R.E., SMITH, R.P. and HODGE, H.C. (1984): Clinical Toxicology of Commercial Products. $5^{\text {th }}$ Edn. Williams and Wilkins: Baltimore/London; 366.

IBRAHIM, B., MBAKCHI, B., MOUNZEO, H., BOUROBOU-BOUROBOU, H.P. and POSSO, P. (2000): Effect of Tephrosia vogelii and Justiciq extensa on Tilapia nilotica in vivo. $J$. Ethnopharmocol., 69:99-104. 
IBRAHIM, M.A. (1984): Evaluation of the Activities of Some West African Traditional Anthelminthic Herbs against Nippostrongylus Brasillensis in Rats. Msc. Thesis, Department of Veterinary Physiology and Pharmacology, Ahmadu Bello University, Zaria; 116.

KA.POSHI, C.K.M. (1992): The Role of Natural Products in Integrated Tick Management in Africa. Status and Recent Advances in Tick Management in Africa. Insect Sci. Applic., 13:595-598.

LAMBERT, N., TROUSLOT, M.F., NEFCAMPA, C. and CHRESTIN, H. (1993): Production of Rotenoids by Heterotrophic and Photomixotrophic Cell Cultures of Tephrosia Vogelii. Phytochem. Oxf., 34:1515-1520.

LOOMIS, T.A. (1978): Essentials of Toxicology. $3^{\text {rd }}$ Edn. Lea and Febiger, Philadelphia; 198.

ILORKE, D. (1983): A New Approach to Practical Acute Toxicity Testing. Arch. Toxicol., 54:275-287.

LUNA, L.G. (1968): Manual of Histologic Staining Methods of the Armed Forees Institute of Pathology. $3^{\text {rd }}$ Edn. The Blakiston Division: McGraw-Hill Book Company, New York; 258.

MARKING, L. (1988): Oral Toxicity of Rotenone to Mammals. U.S. Fish And Wildlife Service, Invest. Fish Cont, 94:5-9.

MATSUMURA, F. (1975): Toxicology of Insecticides. Plenum Press, New York; 503.
NEGHERBON, W.O. (1957): Handbook of Toxicology. Vol. HI. W.B. Saunders, Philadelphia; 665.

O'BRIEN, R.D. and YAMAMOTO, I. (1970): Biochemical Toxicology of Insecticides. Academic Press, New York; 218.

OGENDO, J.O., DENG, A.L., BELMAIN, S.R.., WALKER, D.J. and MUSANDU, A.A.O. (2004): Effect of Insecticidal Plant Materials, Lantana Camara L. And Tephrosia Vogelii Hook, On The Quality Parameters Of Stored Maize Grains. J. Food Tech. Afr., 9:29-36.

WORLD HEALTH ORGANISATION (WHO). (2001): Recommended Classification of Pesticides by Hazard. WHO/PCS/01.4, (2000-01): 89. 